\title{
Evolutionary divergence between sympatric species of southern African Hakes, Merluccius capensis and M. paradoxus. I. Electrophoretic analysis of proteins
}

\author{
W. Stewart Grant, * \\ Inga I. Becker and \\ Rob W. Leslie $†$
}

\author{
Department of Microbiology, University of Cape \\ Town, Rondebosch 7700, South Africa. \\ † Sea Fisheries Research Institute, Private Bag X2, \\ Rogge Bay 8012, South Africa.
}

We estimated the amount of genetic divergence between two morphologically similar species of southern African hake, Merluccius capensis and $\boldsymbol{M}$. paradoxus, with the electrophoretic analysis of proteins encoded by 31 loci. Nei's genetic distance between these taxa was $0.583( \pm 0 \cdot 160)$ and is typical of evolutionary divergence between well differentiated congeneric species. We found no evidence of hybrid individuals. The mean heterozygosity over 13 samples of $M$. capensis was 0.055 and over 10 samples of $M$. paradoxus was $0 \cdot 067$. The present sympatric distributions of these fish are most likely the result of secondary contact after speciation in allopatry or the result of repeated dispersals of ancestral populations of other Atlantic Ocean hakes to southern Africa, rather than the result of sympatric speciation. There were significant excesses of rare alleles in both species as compared with that expected for neutral alleles in species at drift-mutation equilibrium. Average heterozygosities, however, were not appreciably reduced in comparison with other marine fish. Using genetic distance and the assumptions of the molecular clock, we estimate that the lineages leading to these species diverged from one another between 7 and 13 million years ago.

\section{INTRODUCTION}

Isolation in allopatry followed by genetic drift or adaptive divergence appears to be the most common mode of speciation in sexually reproducing animals (Futuyma and Mayer, 1980). Two kinds of population events can lead to allopatric isolation in marine fish. One is the subdivision of an ancestral population into two or more large populations by geologic events or by changes in oceanic currents or temperatures, and the other is the establishment of small founder populations outside of a species' usual geographic range. The sympatric occurrence of closely related species is therefore assumed to reflect secondary contact after the formation of reproductive barriers has prevented reassimilation into a single gene pool.

In this paper we describe genetic divergence between two sympatric species of hake, Merluccius capensis and $M$. paradoxus, which inhabit the coas-

\footnotetext{
* Present address: Department of Genetics, University of the Witwatersrand, Johannesburg 2050, South Africa.
}

tal waters of southern Africa. Merluccius capensis is distributed between $12^{\circ} \mathrm{S}$ on the west coast and $31^{\circ} \mathrm{E}$ on the south coast. 'Merluccius paradoxus, in contrast, has a more restricted range between $18^{\circ} \mathrm{S}$ and $27^{\circ} \mathrm{E}$ (Inada, 1981). The ranges of these hakes coincide with the cool temperate waters of the Benguela Upwelling System and are bounded by the warm southward flowing Southern Equatorial Current on the west coast and the southwestward flowing Mocambique Current on the south coast. There is a broad area of bathymetric overlap; Merluccius capensis inhabits the continental shelf to about $400 \mathrm{~m}$, and $M$. paradoxus inhabits the continental shelf and slope from about $140 \mathrm{~m}$ to $850 \mathrm{~m}$.

The taxonomies of species in the genus Merluccius are in considerable disarray because many species are morphologically similar to one another. The two nominal species of southern African hake were considered to be a single species, $M$. capensis, until Franca (1954) demonstrated the existence of a second sympatric taxon, $M$. paradoxus, from a study of vertebral numbers. Subsequent morphological studies (van Eck, 1969; Bentz, 1976) and 
an electrophoretic study of non-specific proteins (Jones and Mackie, 1970) have confirmed Franca's (1954) hypothesis of two distinct taxa. The actual amount of genetic divergence between these species and their phylogenetic relationships to other species of hake, however, are still matters of much speculation (Szidat, 1961; Franca, 1971; Meyer-Rochow, 1972; Kabata and Ho, 1981).

The goal of this study is to document genetically-based electrophoretic variation in these taxa and to estimate the amount of genetic divergence between them. The following paper in this issue reports genetic divergence between these taxa as measured by the restriction-endonuclease analysis of mitochondrial DNA (Becker et al., 1988). Subsequent papers in this series will examine the phylogenetic relationships of these taxa with other Atlantic and Pacific Ocean hakes.

\section{MATERIALS AND METHODS}

We examined genetic variation in a total of 1135 individuals of Merluccius capensis from 13 locations (extending from $18^{\circ} 42^{\prime} \mathrm{S}, 11^{\circ} 48^{\prime} \mathrm{E}$ to $34^{\circ} 20^{\prime} \mathrm{S}$, $25^{\circ} 40^{\prime} \mathrm{E}$ ), and a total of 882 individuals of $M$. paradoxus from 10 locations $\left(23^{\circ} 02^{\prime} \mathrm{S}, 13^{\circ} 05^{\prime} \mathrm{E}\right.$ to $34^{\circ} 40^{\prime} \mathrm{S}, 25^{\circ} 40^{\prime} \mathrm{E}$ ) (fig. 1). Samples of eye, liver, skeletal and cardiac muscles were held at $-25^{\circ} \mathrm{C}$ for up to 3 months until laboratory analysis. Individuals were identified to species by gill arch tubercle morphology (van Eck, 1969). Starch-gel electrophoretic methods followed May et al. (1979), and staining protocols followed Shaw and Prasad (1970) and Harris and Hopkinson (1976). To facilitate comparison between species, alleles for each locus were designated by their electrophoretic mobilities relative to the most common allele in $M$. capensis for that locus. Alleles with products migrating cathodally were prefixed with a minus sign.

The gene-products of the following 31 homologous loci were examined in each species. We used a discontinuous lithium-borate tris-citric acid buffer $(p \mathrm{H} 8.1$; Ridgway et al., 1970) to examine variation for creatine kinase $(C k-A$ and $C k$ - B, EC 2.7.3.2), glucosephosphate isomerase (Gpi-A and $G p i-B$, EC 5.3.1.9), lactate dehydrogenase ( $L d h-A, L d h-B$ and $L d h-C, E C 1.1 .1 .27$ ), phosphoglucomutase (Pgm-1 and Pgm-2, EC 2.7.5.1), phosphogluconate dehydrogenase ( $P g d$, EC 1.1.1.44), non-specific protein $(P t-1, P t-2, P t-3$, $P t-4, P t-5)$, superoxide dismutase (Sod-1, EC 1.15.1.1) and sorbitol dehydrogenase $(S d h$, EC 1.1.1.14). We used a tris-citric acid buffer ( $p \mathrm{H} \mathrm{6.9}$;
Whitt, 1970) to examine glyceraldehyde phosphate dehydrogenase (Gap-1 and Gap-2, EC 1.2.1.12), glycerol-3-phosphate dehydrogenase (Gpd-A, $G p d-B$ and $G p d-C$, EC 1.1.1.8), isocitrate dehydrogenase (Idh-A, EC 1.1.1.42), malate dehydrogenase ( $M d h-A$ and $M d h-B$, EC 1.1.1.37), malate dehydrogenase-NADP ${ }^{+}$(=malic enzyme, $\mathrm{Me}$, EC 1.1.1.40), and a tris-borate-EDTA buffer ( $p \mathrm{H}$ 8.7; Markert and Faulhaber, 1965) to examine guanine deaminase ( $G d a$, EC 3.5.4.3), mannosephosphate isomerase (Mpi, EC 5.3.1.8), nucleoside phosphorylase $(N p$, EC 2.4.2.1) and peptidase (Pep-D, EC 3.4.13.9 and Pep-X, EC 3.4.?.?).

\section{RESULTS}

We identified the gene products of 31 proteincoding loci by the criteria of Allendorf and Utter (1979) and by comparison with other related teleosts. Proteins encoded by $C k-B, G a p-2, G p d-A$, Gpd-B, Ldh-C, Pep-X, Pt-1,Pt-2,Pt-3,Pt-4 and $S d h$ appeared as invariant bands on the gels with the same mobilities for both species. The products of $N p$ and $P t-5$ were invariant within species but were fixed for different alleles between species. Three enzymes encoded by $M p i, P g m-1$ and Pgm-2 (fig. 3) showed double-banded heterozygous phenotypes in one or both species. Ten proteins encoded by $G d a, G p d-C, G p i-A, G p i-B$ (fig. 2), $I d h-A, M d h-A, M d h-B, P e p-D, P g d$ and Sod-1 had triple-banded heterozygotes typical for dimeric enzymes in at least one species. Although a dimer, $C k-A$ exhibited double-banded heterozygous phenotypes typical for teleosts (Ferris and Whitt, 1978). The products of Gap-1, $L d h-A, L d h-B$ and Me showed broad-banded or five-banded heterozygous phenotypes typical for tetrameric enzymes in at least one species.

The amount of genetic variation present in both species was very similar. In $M$. capensis, 13 of 31 loci ( 41.9 per cent) showed at least some polymorphism and 7 loci ( 22.6 per cent $)$ had commonallele frequencies less than 0.95 in at least one sample, In $M$. paradoxus, 13 loci $(41.9$ per cent) were polymorphic, and 8 loci ( 25.8 per cent) were polymorphic using the 0.95 criterion of polymorphism. The proportion of expected heterozygotes at a locus may be defined by

$$
h=1-\sum x_{i}^{2}
$$

where $x_{i}$ denotes the frequency of the ith allele. Average heterozygosity $(\bar{H})$ is the arithmetic mean of $h$ over all loci including monomorphic loci. In 


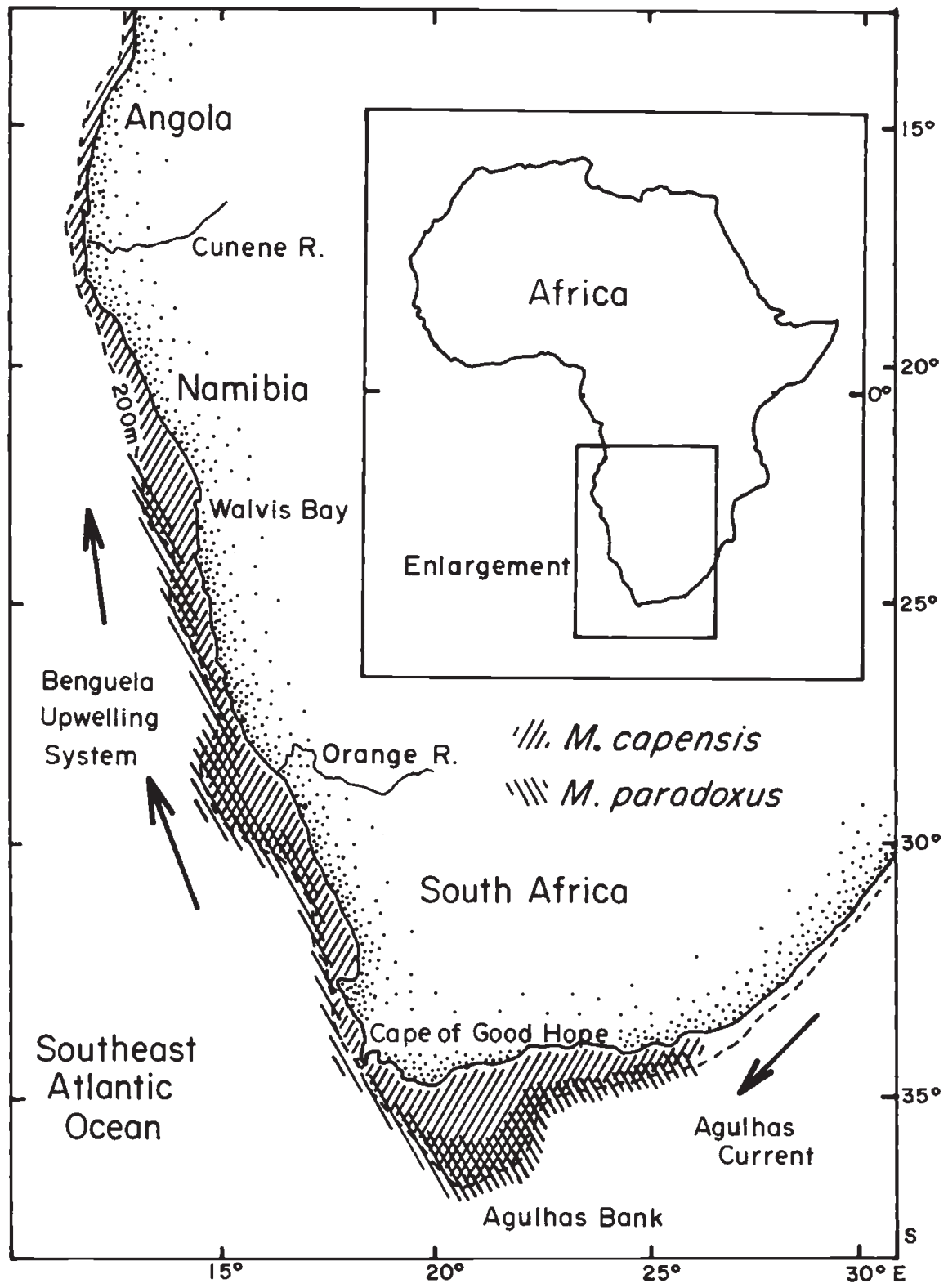

Figure 1 Geographic distributions of southern African hakes, Merluccius capensis and M. paradoxus.

M. capensis, $\bar{H}$ per sample ranged from 0.046 to 0.055 and averaged $0.051( \pm 0.023)$ over 13 samples. $\vec{H}$ for $M$. paradoxus ranged between 0.059 and 0.070 and averaged $0.063( \pm 0.026)$ over 10 samples. The difference between these two average values of $H$ was not significant ( $t$-test on arcsin transforms of locus heterozygosities; Archie, 1985).

The relative amounts of subdivision at different levels of population organisation was summarised by the gene diversity statistics of Nei (1973) with the computing algorithm of Chakraborty et al. (1982). Total gene diversity $\left(H_{\mathrm{T}}\right.$; heterozygosity of pooled allele frequencies) was partitioned into two components

$$
H_{\mathrm{T}}=H_{\mathrm{S}}+D_{\mathrm{ST}}
$$

where $H_{\mathrm{S}}$ is the average subpopulation heterozygosity and $D_{\mathrm{ST}}$ is the proportion of $H_{\mathrm{T}}$ that is due to differences between subpopulations. Therefore, 


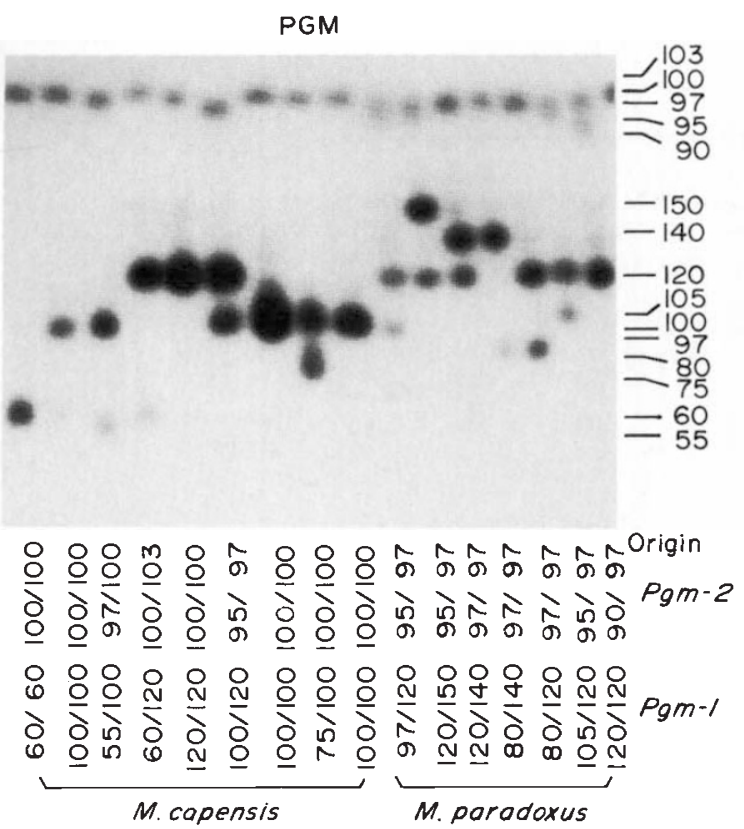

Figure 2 Electrophoretic variability for phosphoglucomutase in muscle tissues of Merluccius capensis (C) and Merluccius paradoxus ( $\mathrm{P})$.

$H_{\mathrm{S}} / H_{\mathrm{T}}$ is the relative proportion of the total gene diversity that is contained within subpopulations and was 0.983 and 0.987 for $M$. capensis and $M$. paradoxus, respectively. $G_{\mathrm{ST}}=D_{\mathrm{ST}} / H_{\mathrm{T}}$ is the relative proportion of the total diversity that is due to differences between subpopulations and was 0.017 and 0.013 for $M$. capensis and $M$. paradoxus, respectively. Since these values represent very low levels of population differentiation, allele frequencies were pooled by species for further analysis (table 1).

Genetic identities between taxa for a locus may be computed from allele frequency data by

$$
I=J_{\mathrm{xy}} /\left(J_{\mathrm{x}} J_{\mathrm{y}}\right)^{1 / 2}
$$

where $J_{\mathrm{xy}}$ is the probability of identity of two alleles drawn at random, one each from populations $x$ and $y$ (Nei, 1972). This probability is standardised by the geometric mean of the probabilities of identity within populations $x$ and $y$. An estimate of $I$ over all loci may be computed by averaging $J_{\mathrm{xy}}$, $J_{\mathrm{x}}$ and $J_{\mathrm{y}}$ over loci. Genetic distance $(D)$ is defined as

$$
D=-\log _{\mathrm{e}} I .
$$

Nei and Roychoudhury (1974) present a formula for computing the standard error of $D$. The average $D$ (31 loci) between pairs of samples of $M$. capensis

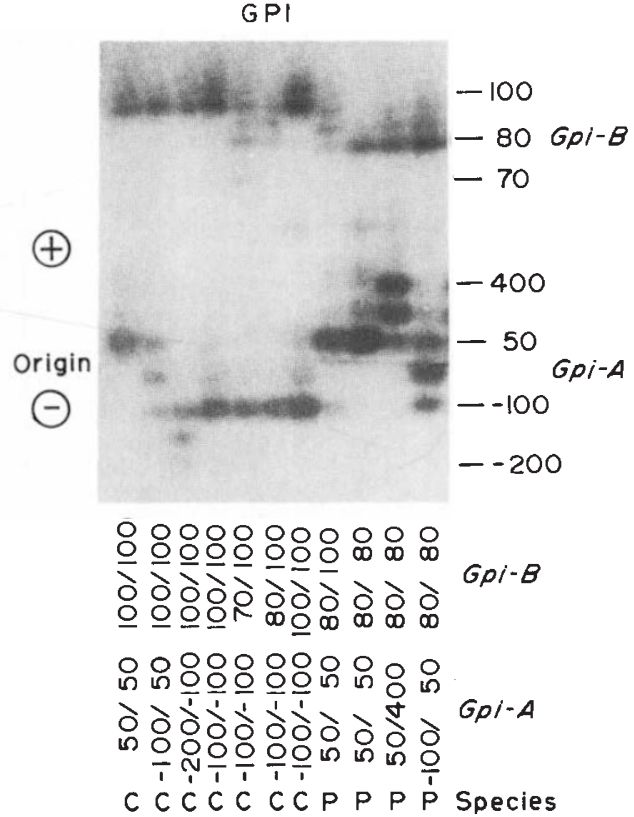

Figure 3 Electrophoretic variability for glucosephosphate isomerase in muscle tissues of Merluccius capensis $(\mathrm{C})$ and Merluccius paradoxus (P).

was 0.0007 and that between pairs of samples of $M$. paradoxus was $0 \cdot 0006$. I between the two species was $0 \cdot 558( \pm 0 \cdot 160)$ and $D$ between species was $0.583( \pm 0 \cdot 160)$.

\section{DISCUSSION}

Several loci were fixed or nearly fixed for different alleles between these species and we interpret this as convincing evidence that $M$. capensis and $M$. paradoxus do not share a common gene pool. We also did not observe any individuals with hybrid genotypes. Several studies show that there is generally good agreement between traditional taxonomy and molecular distance. In some instances, however, where there is little morphological differentiation, as with the hakes in the present study, molecular distance may then be used as a guide to taxonomy. Thorpe (1982) summarised genetic distance data for 2664 pairs of taxa of invertebrates and vertebrates and found that an average $D$ between congeneric species was $0 \cdot 62$. In a review of genetic distances specifically between fish taxa, Shaklee et al. (1982) found that for pairs of taxa classified as related species, $D$ ranged from $0 \cdot 025$ to 0.65 and averaged $0 \cdot 30$. Thus our finding of $D=0.583$ between these two hakes indicates that they should be treated as full species. 
Table 1 Summary of alleles frequencies for southern African hakes, Merluccius capensis and M. paradoxus. Alleles are arranged according to their electrophoretic mobility beginning from the cathodal end of the gel

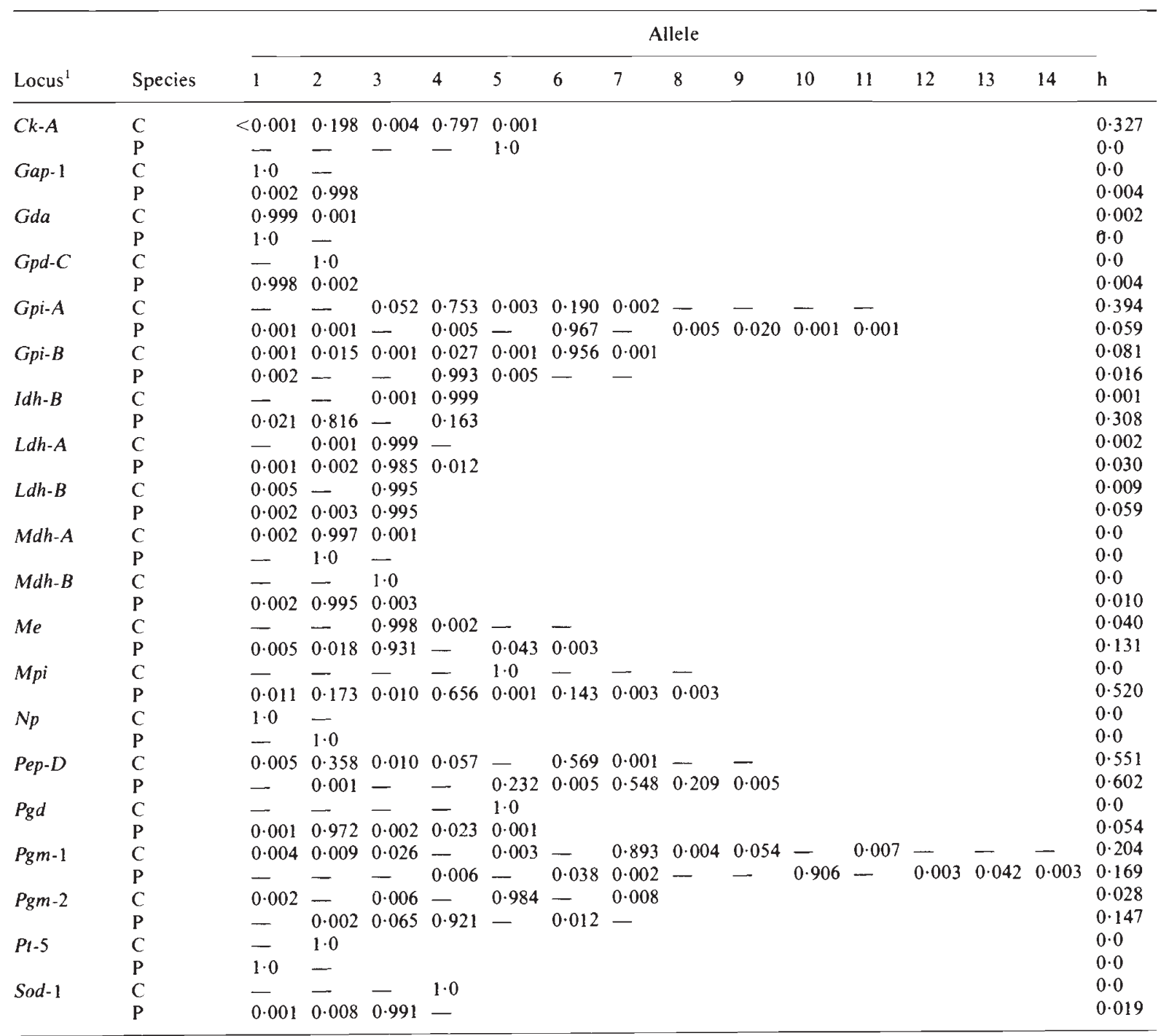

${ }^{1}$ The following loci were fixed for the same allele in both species $C h-B, G a p-2, G p d-A, G p d-B, L d h-C, P e p-X, P t-1, P t-2, P t-3, P t-4$ and $S d h$.

Average heterozygosity for $M$. capensis was 0.051 and that for $M$. paradoxus was 0.063 and both values were similar to those found in other fishes. Winans (1980) summarised average heterozygosity in 82 fish and found an overall average of $0 \cdot 048 \pm 0 \cdot 033$. In the infiite alleles model of neutral mutations the expected heterozygosity in an equilibrium population is equal to $4 N_{\mathrm{e}} v$, where $N_{\mathrm{e}}$ is the effective population size and $v$ is the mutation rate per locus per generation (Kimura and Crow, 1964). Fuerst et a. (1977) have generated theoretical distributions of locus heterozygosities for equilibrium populations having a specific average heterozygosity. A comparison of the observed distribution of locus heterozygosities in the two hakes with that expected under the infinitealleles model for $H=0.05$ is shown in fig. 4. This agreement suggests that these populations are in drift-mutation equilibrium.

An examination of the distributions of expected and observed allele frequencies, however, gives a different picture. When a bottleneck in population size occurs, as for instance in a small founder population, average heterozygosity declines by 

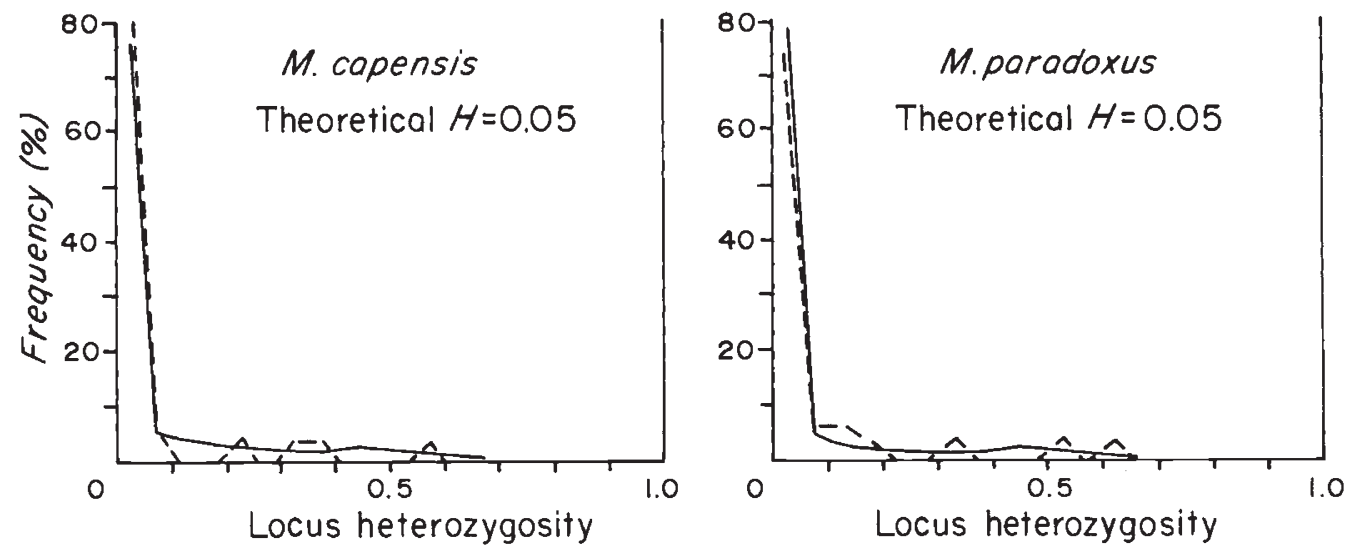

Figure 4 Comparisons of observed (broken line) locus heterozygosities with theoretical (solid line) distributions of heterozygosities expected at equilibrium in the infinite-alleles model of mutation.

1/ $\left(2 N_{\mathrm{e}}\right)$ for a one time bottleneck (Nei et al., 1975; Chakraborty and Nei, 1977). If population growth is slow after the bottleneck, heterozygosity continues to decline. With time, new alleles appear through mutation and accumulate in the population at a rate that depends upon $4 N_{\mathrm{e}} v$. But there is a delay in the return to original levels of heterozygosity as rare alleles drift to intermediate frequencies (Maruyama and Fuerst, 1984). Thus during the transit to equilibrium, there is an excess of low-frequency alleles compared with that expected for a given value of $H$ in populations at driftmutation equilibrium.

We compared the observed distributions of the number of alleles at different allele frequencies with the expected distributions under the infinite allele model of neutral mutations. The expected number of alleles with frequencies between $p$ and $q$ is

$$
n(p, q)=\sum_{i=N_{p}+1}^{N q} \theta N_{\mathrm{i}} / i(\theta+N-1)_{\mathrm{i}}
$$

where $N$ is the total number of genes sampled and $\theta=4 N_{\mathrm{e}} v=H /(1-H)$ (p. 400, Waterson, 1984). This theoretical distribution for 0.05 frequency intervals is compared with the observed distributions of the two hakes in fig. 5. It is apparent that there is a large excess of alleles with frequencies
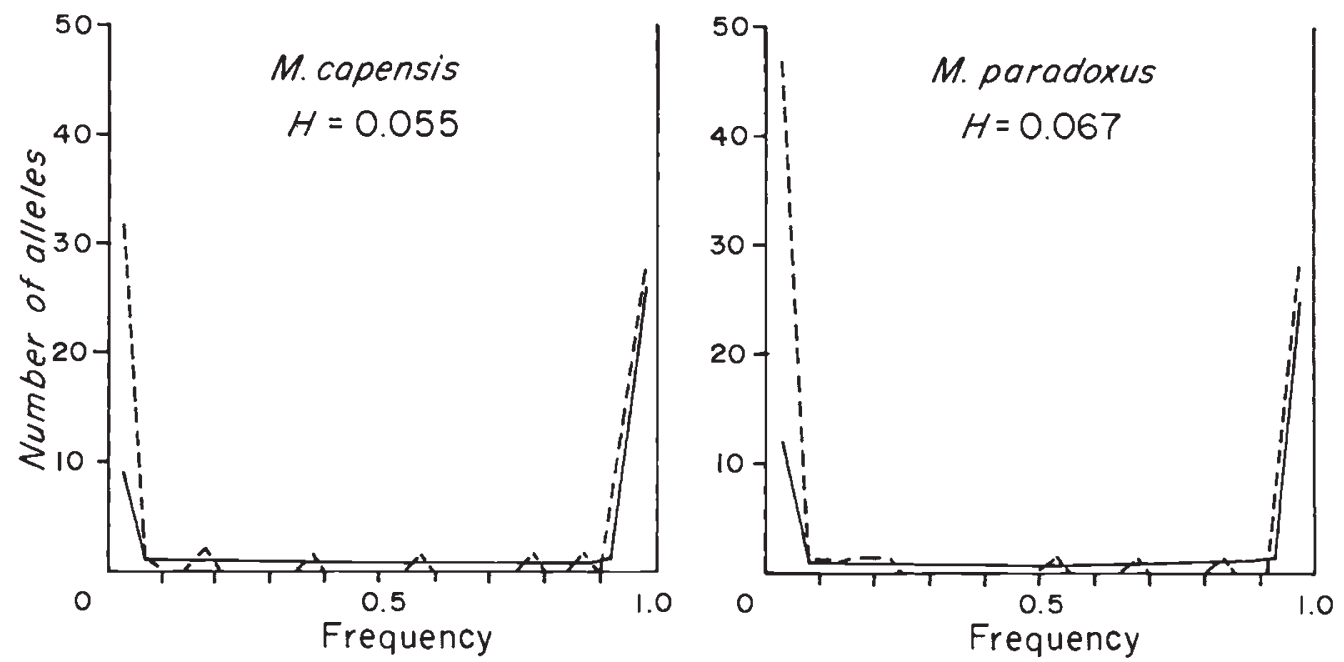

Figure 5 Comparisons of observed (broken line) numbers of alleles at 0.05 frequency intervals with the theoretical (solid line) distribution expected at equilibrium in the infinite-alleles model. 
less than 0.05 for both species. The KolmogorovSmirnov test (Sokal and Rohlf, 1981) for fit to the theoretical distribution indicates that this deviation is highly significant for both $M$. capensis $\left(D_{67}=\right.$ $0.337, \mathrm{P}<0.01)$ and $M$. paradoxus $\left(D_{84}=0.424\right.$, $\mathrm{P}<0.01)$.

The time needed to reach equilibrium for neutral genes is very long for species such as hakes that have large population sizes. The rate of approach to equilibrium is of the order $2 v+$ $1 /\left(2 N_{\mathrm{e}}\right)$ each generation. For these hakes, which presently have species effective population sizes of at least $10^{8}$ (Payne et al., 1986) and an estimated mutation rate of about $10^{-7}$ (Kimura and Ohta, 1971), the time to equilibrium is on the order of 10 million years or more. Thus, the effects of even an ancient bottleneck may still be apparent in allele-frequency distributions.

Genetic distance may be used to estimate the amount of time since divergence began between two taxa. Empirical calibrations of $D$ with time suggest that a $D$ of 1.0 is equal to about 19 million years of isolation (Carlson et al., 1978; Vawter et al., 1980). Critics of the electrophoretic molecular clock concept, however, have pointed out that there are large errors associated with the clock because of errors in calibration (Radinsky, 1978), because of sampling proteins with different evolutionary rates (Skibinski and Ward, 1982) and because of the stochastic nature of the clock (Fitch, 1976). Thus, we suggest that only a period of time may realistically be computed using $D$ and its standard error to estimate when divergence most likely began. For the two southern African Hakes this period of time extends from 7.6 to 13.6 million years ago. This estimate represents the time when the lineages leading to the two species split.

There are two biogeographic scenarios that may explain the sympatric distributions of these fishes in southern Africa. The first is that past episodes of oceanic cooling (CLIMAP 1976; Shannon 1985) displaced northward and isolated ancestral populations of southern African Merluccius, This seems unlikely, however, because paleo-oceanographic evidence suggests that the southward-flowing warm Agulhas Current from the Indian Ocean persisted during periods of Pliocene and Pleistocene cooling (Shannon, 1985). The more likely explanation is that the two species represent different biogeographic dispersals of North Atlantic taxa along the west coast of Africa. If so, the species representing the more recent dispersal may show a greater genetic affinity to one of the North Atlantic hakes. We are, presently, collecting samples of other hakes to test this hypothesis.
Acknowledgments We thank Dr E. MacPherson and the crew of the M.F.V. Chicha Touza, Instituto de Investigaciones Pesqueras, Barcelona, Spain for collection of samples in Namibia and C. Hart and the crew of the R.V. Africana for samples in South Africa. Dr Wessels of the Fishing Research Institute, University of Cape Town provided laboratory facilities. This study was supported by the Sea Fisheries Research Institute, Cape Town.

\section{REFERENCES}

ARCHIE, J. W. 1985. Statistical analysis of heterozygosity data: independent sample comparisons. Evolution, 39, 623-637.

BECKER, I. I., GRANT, W. S., KIRBY, R. AND ROBB, F. T. 1988. Evolutionary divergence between sympatric species of southern African Hakes, Merluccius capensis and $M$. paradoxus. II. Restriction enzyme analysis of mitochondrial DNA. Heredity, 61, 21-30.

BENTZ, K. L. M. 1976. Gill arch morphology of the Cape hakes, Merluccius capensis Cast. and M. paradoxus Franca. Fish. Bull. S. Afr., 8, 17-22.

BOTHA, L. 1980. The biology of the Cape Hakes Merluccius capensis Cast. and M. paradoxus Franca in the Cape of Good Hope Area. Ph.D. Thesis, University of Stellenbosch, South Africa, 182pp.

Cabo, F. L. 1965. Las merluzas atlanticas. Publ. Dir. Gen. Pesca. Marit., 4, 208.

CARLSON, S. S., WILSON, A. C. AND MAXSON, R. L. 1978. Do albumin clocks run on time? A reply. Science, 200, 11831185.

CHAKRABORTY, R. AND NEI, M. 1977. Bottleneck affects on average heterozygosity and genetic distance with the stepwise mutation model. Evolution, 31, 347-356.

CHAKRABORTY, R., HAAG, M., RYMAN, N. AND STAHL, G. 1982. Hierarchical gene diversity analysis and its application to brown trout population data. Hereditas, 97, 17-22.

CLIMAP. 1976. The surface of the ice-age earth. Science (Wash., DC) $191,1131-1137$.

FITCH, W. M. 1976. Molecular evolutionary clocks. In Ayala, F. J. (ed.) Molecular Evolution, Sinauer Assoc. Inc., Sunderland, Massachusetts, pp. 160-178.

FERRIS, S. and WHITT, G. 1978. Genetic and molecular analysis of nonrandom dimer assembly of the creatine kinase isozymes of fishes. Biochem. Genet., 16, 811-829.

FRANCA, P. 1954. Contribuicao para o conhecimento do genero Merluccius no Atlantico oriental ao sul do equador. Trabhs. Miss. Biol. Marit., 8, 46-98.

FRANCA, P. 1971. Hipoteses acerca da provavel ocorrencia de Merluccius merluccius paradoxus Franca $1960 \mathrm{em}$ aguas Angolanas. Not. Cent. Biol. Aquat. Trop., 26, 1-18.

FUERST, P. A., CHAKRABORTY, R. AND NEI, M. 1977. Statistical studies on protein polymorphism in natural populations $I$. distribution of single locus heterozygosity. Genetics, 86 , $455-483$.

FUTUYMA, D. J. AND MAYER, G. C. 1980. Non-allopatric speciation in animals. Syst. Zool., 29, 254-271.

INADA, T. 1981. Studies on the Merlucciid fishes. Bull., Far Seas Fish. Res. Lab., Shimizu, Japan 18, 1-172.

JONES. B. W. AND MACKIE, I. M. 1970. On application of electrophoretic analysis of muscle myogens to taxonomic studies in the genus Merluccius. Comp. Biochem. Physiol, $32,267-273$.

KABATA, Z., AND HO, J.-S. 1981. The origin and dispersal of hake (genus Merluccius: Pisces: Teleostei) as indicated by its copopod parasites. Oceanogr. Mar. Biol. Ann. Rev., 19, $381-404$. 
KIMURA, M. AND CROW, J. F. 1964. The number of alleles that can be maintained in a finite population. Genetics, 49 , 725-738.

Kimura, M. ANd Ohta, T. 1971. Protein polymorphism as a phase of molecular evolution. Nature, 229, 467-469.

MARKERT, C. L. AND EAULHABER, I. 1965. Lactate dehydrogenase isozyme patterns of fish. J. Expl. Zool., 159, 319-332.

MARuyama, T., AND FUerst, P. A. 1984. Populations bottlenecks and nonequlibrium models in population genetics. I. Allele numbers when populations evolve from zero variability. Genetics, 108, 745-763.

MAY, B., SHAKLEE, J. B. AND STONEKING, M. 1979. Joint segregation of biochemical loci in Salmonidae: results from experiments with Salvelinus and review of the literature on other species. J. Fish. Res. Bd. Can., 36, 1114-1128.

MEYER-ROCHOW, V. B. 1972. A note on some parasites of Merluccius capensis (Pices) and their zoogeographical significance. Afr. J. Trop. Hydrobiol. Fish., 2, 82-84.

NEI, M. 1972. Genetic distance between populations. Amer. Natur., 106, 283-292.

NEI, M. 1973. Analysis of gene diversity in subdivided populations. Proc. Natl. Acad. Sci. USA, 70, 3321-3323.

NEI, M. AND ROYCHOUDHURY, A. K. 1974. Sampling variances of heterozygosity and genetic distance. Genetics, 76, 379390.

NEl, M., MARUYAMA, T. AND CHAKRABORTY, R. 1975. The bottleneck effect and genetic variability in populations. Evolution, 29, 1-10.

PAYNe, A. I. L., AUgustyn, C. J. AND Leslie, R. W. 1986. Biomass index and catch of Cape hake from random stratified sampling cruises in division 1.6 during 1984. Colln. Scient. Pap. Int. Comm. SE Atl. Fish., 12, 99-123.

RADINSKY. L. 1978. Do albumin clocks run on time? Science, $200,1182-1183$.

RIDGWAY, G. J., SHERBOURNE, S. W. AND LEWIS, R. D. 1970. Polymorphism in the esterses of Atlantic herring. Trans. Am. Fish. Soc., 99, 147-151.
ROSEN, D. E. 1978. Vicariant patterns and historical explanation in biogeography. Syst. Zool, 27, 159-188.

SHAKLEE, J. B., TAMARU, C. S. AND WAPLES, R. W. 1982 Speciation and evolution of marine fishes studied by the electrophoretic analysis of proteins. Pac. Sci., 36, 141-157.

SHANNON, L. V. 1985. The Benguela ecosystem. Part. I. Evolution of the Benguela physical features and processes. Oceanogr. Mar. Biol. Ann. Rev., 23, 105-182.

SHAW, C. R. AND PRASAD, R. 1970. Starch gel electrophoresis of enzymes-a compilation of recipes. Biochem. Genet., 4, 297-320.

SKIBINSKI, D. O. F. AND WARD, R. D. 1982. Correlation between heterozygosity and evolutionary rate of proteins. Nature, 298, 490-492.

SOKAL, R. R., AND ROHLF, R. J. 1981. Biometry. 2d. ed., Freeman and Co., San Francisco, CA. 859 p.

SZIDAT, L. 1961. Versuch einer Zoogeographie des Sud-Atlantik mit Hilfe von Leitparsiten der Meeresfische. Parasitol Schr. Reihe, 13, 1-98.

THORPE, J. P. 1982. The molecular clock hypothesis: bio. chemical evolution genetic differentiation and systematics. Ann. Rev. Ecol. Syst., 13, 139-168.

VAN ECK, T. H. 1969. The South African hake: 'Merluccius capensis'-or 'Merluccius paradoxus'? S. Afr. Shipp. News Fish. Ind. Rev., 24, 95-97.

WAWTER, A. T., ROSENBLATT, R. AND GORMAN, G. C. 1980 Genetic divergence among fishes of the Eastern Pacific and the Caribbean: Support for the molecular clock. Evolution, 34, 705 711.

WATTERSON, G. A. 1984. Allele frequencies after a bottleneck. Theor. Pop. Biol., 26, 387-407.

WHITT, G. S. 1970. Developmental genetics of the lactate dehy. drogenase isozymes of fish. $J$. Expl. Zool., 175, 1-35.

WINANS, G. 1980. Geographic variation in the milkfish Chanos chanos. I. Biochemical evidence. Evolution, 34, 558-574. 